\title{
Evaluation of Percutaneous Disc Decompression Using Coblation in Chronic Back Pain With or Without leg Pain
}

\author{
Vijay Singh, MD, Chandur Piryani, MD, and Katherine Liao, MD
}

The intervertebral disc is the focal point months post procedure. of pathology for most low back pain. Contained disc herniation is a common cause of low back pain and, when unresponsive to conservative measures, is often treatable by disc decompression.

To evaluate the safety and efficacy of percutaneous disc decompression using Coblation (Nucleoplasty) in the treatment of back and/or leg pain associated with contained disc herniation, a prospective, nonrandomized cohort analysis was conducted in an interventional pain management practice. Patients were followed for twelve

The intervertebral disc is an important component of the spine. Degeneration or herniation of the disc may not only produce discogenic or compressionrelated pain but may also significantly influence the integrity of other load bearing structures within the spine $(1,2)$.

Maintenance of disc integrity is directly correlated with supply of nutrients and removal of waste from the cells of the nucleus pulposus, however the central disc is an avascular structure. The majority of nutrients passing to the central disc are diffused through the endplates while a lesser amount travels through the anulus fibrosus (3). The central disc cells may be 6- $8 \mathrm{~mm}$ away from either of these structures, forcing them to function in an anaerobic environment (4-7). With aging, disease, or injury, the structures through which nutrients diffuse may become less permeable to the essential blood supply, forcing more of the disc to function anaerobically. This nutritional suffocation provides an intradiscal environment

From Pain Diagnostics Associates, Niagara, Wisconsin. Address Correspondence: Vijay Singh, MD, 1601, Roosevelt Road, Niagara, WI 54151 . E-mail: vsingh@netnet.net

Funding: There was no external funding in preparation of this manuscript.
Eighty patients who presented with discogenic low back pain with or without radicular pain associated with contained disc herniation underwent percutaneous disc decompression using Coblation ${ }^{\mathrm{TM}}$ technology (Nucleoplasty ${ }^{\mathrm{TM}}$ ) after failing at least 3 months of conservative and injection therapies.

Overall, $75 \%$ of patients indicated a decrease in their numeric pain scores at 12 months with a statistically significant reduction in numeric pain scores of $2.43 \pm 2.47$ (p<0.0001) compared to baseline. A total of $54 \%$ of patients indicated pain relief of $50 \%$ or more at twelve months. Additionally, significant improvement was reported by $54 \%, 44 \%$, and $49 \%$ of patients in sitting, standing and walking abilities, respectively, at 12 months. There were no instances of complications.

These results indicate that disc decompression using Coblation (Nucleoplasty) is a safe and efficacious procedure for reducing discogenic low back pain with or without leg pain.

Keywords: Percutaneous disc decompression, nucleotomy, contained disc herniation, discogram, coblation, nucleoplasty, radiofrequency, discitis where cell degeneration is inevitable.

As disc degeneration progresses, a volume loss occurs within the nucleus pulposus due to a decrease in proteoglycan and water concentration, which may or may not be accompanied by structural changes in the endplate (8). Due to the lack of nutrients and oxygen, the cells are forced to metabolize anaerobically, generating large amounts of lactic acid, increasing acidity and further degrading the intradiscal matrix $(3,9)$. The strength of the lumbar disc depends on the fluid exchange and balance of proteoglycan synthesis and breakdown within the matrix. As these components decrease, the applied load is transferred to the anulus and posterior elements of the spine (10). This transfer greatly increases the probability of anular tear and/or herniation $(11,12)$.

The outer rim of the annulus is innervated by the meningeal branch of the recurrent sinuvertebral nerve, as well as the rami communicantes from multiple superior and inferior dorsal root ganglia (13-15). With degeneration, anular tearing, and herniation, these nerves may further invade the deeper intradiscal structures as far as the outer rim of the nucleus pulposus and create additional pain reception sites within the disc itself (16-20).
Outside of the disc, the anterior and posterior longitudinal ligaments, which may be stretched by herniation or chemically irritated by the release of inflammatory chemicals from within the disc, are also richly innervated, providing another potential pain source (15).

Despite the multiple pain reception regions within the disc and spine, disc degeneration often occurs without any related discomfort. Herniations are present in up to $28 \%$ of asymptomatic individuals (19). Symptomatic disc herniation may be treated using a variety of modalities.

In 1934, Mixter and Barr (21) identified disc herniation as a source of radicular symptoms, and since then discectomy has been the most prevalent treatment for this condition. In the case of low back pain arising from contained disc herniations, Carragee et al (22) have reported that open surgical discectomies have a high failure rate $(76 \%)$ when size of the herniation is less than $6 \mathrm{~mm}$. In a separate prospective observational study (23) of 187 patients looking at the effects of fragment type and annular competence on clinical outcomes after lumbar discectomy, they reported that patients with no-fragment, contained group did poorly (38\% recurrent or persistent sciatica) 
compared to those with fragments.

Size and type of herniation is, however, only one of the factors in the success of disc decompression for symptomatic herniation. Amount of disc material removed has a significant impact on the success of discectomy (24). In one of the reports, data collected on 42 patients treated with automated percutaneous discectomy, indicated that patients who had undergone treatment with a $2 \mathrm{~mm}$ Nucleotome with removal of $1.95 \mathrm{~g}$ of disc material reported more satisfaction than those treated with a $2.5 \mathrm{~mm}$ Nucleotome with removal of, on average, $3.88 \mathrm{~g}$ of disc material (25). A two-fold decrease in success rates for discectomy, from $71 \%$ to $36 \%$, was seen in patients with a large amount of disc material removed, averaging $3.8 \mathrm{~g}$ including the central area of the nucleus, in contrast to removal of the hernial mass or migrated nucleus, averaging $1 \mathrm{~g}$. In addition, there was a more pronounced and rapid decrease in disc height coupled with a more drastic and pronounced increase in disc dehydration in the patients where a larger amount of material was excised (26). Mochida et al (26), during their analysis of disc material removal, have concluded that nucleotomy to reduce disc herniation should mimic asymptomatic disc degeneration and should therefore produce a gradual degenerative course, which cannot be achieved with removal of a large amount of disc material.

Annular integrity may be another important variable in achieving a more beneficial outcome for patients undergoing disc decompression. Annular repair occurs very gradually and a large incision into a degenerated-herniated disc will result in a decrease in anular strength during the healing process (27). Analysis of proteoglycan synthesis and degradation indicate that replacement of proteoglycan molecules within the disc may take up to 3 years (28). Three separate analyses have concluded that the box incision method leads to significantly poorer healing (29), a decrease in strength of $40-50 \%$ (30), and an increase in severe and early disc degeneration (27). Another analysis (31) indicated that square, circular, cross, and slit incisions each produce a larger range in motion during axial moment loadings. Annular entry with a $2.5 \mathrm{~mm}$ OD trocar, maintained disc integrity during biomechanical loading (30).

Another important factor affecting the outcome after surgical procedures is formation of adhesions and scar tissue. Adhesions between the posterior anulus and the nerve root are common following discectomies (32). Patients with post-operative scar tissue have been reported to have more severe complications (33). In comparison, epidural and foraminal adhesions and scarring is greatly reduced following minimally invasive, percutaneous procedures.

Percutaneous intradiscal entry is required for minimally invasive disc decompressive techniques. In view of the growing knowledge regarding the factors affecting annular healing and disc integrity, it has become imperative to search for techniques, which are minimally disruptive to the annular structure.

In the last two decades, there has been a gradual evolution in minimally invasive procedures. Among the several minimally invasive disc decompression techniques, the most recent is percutaneous disc decompression (PDD) using Coblations ${ }^{\mathrm{TM}}$ plasma technology (Nucleoplasty ${ }^{\mathrm{TM}}$ ), with a minimally invasive percutaneous entry into the disc via a 17gauge cannula and removal of approximately $1 \mathrm{~g}$ of disc tissue from the nucleus pulposus.

Since it was approved for use in spine in 2000, PDD with Coblation has been widely used. Within the last year, several analyses have been published on the efficacy of this technique. However the patient sample size of 1-year follow-up were relatively small. Follow-up data at 1 year was reported for 13 patients by Sharps and Isaac (34) and 41 patients by Singh et al (35) while 6 months data included 14, 30, and 45 patients respectively (36-38). Based on the encouraging results from these initial studies the current analysis was undertaken to include a larger patient sample prospectively followed for 1year.

\section{Methods}

\section{Design and Participants}

A prospective, nonrandomized cohort analysis was conducted on 80 consecutive patients who underwent Percutaneous Disc Decompression using Coblation (Nucleoplasty) between October 2000 and March 2002.

Criteria for inclusion were the presence of discogenic low back pain and/or leg pain for three or more months, absence of neurologic deficit, lack of response to conservative management and fluoroscopically guided injection therapies. The diagnosis of discogenic pain was confirmed with positive provocative discography with elicitation of concordant pain and identification of at least one control disc negative for provoked pain.

Exclusion criteria for this outcome analysis included presence of secondary gain issues, heavy opioid usage, and uncontrolled psychological disorders. Contra-indications for the procedure, were evidence of infection, disc herniation with sequestration, large contained herniation occupying one-third or more of the spinal canal, marked spinal stenosis due to extensive osteophytosis, and equivocal discography results.

\section{Procedure}

Percutaneous disc decompression using Coblation (Nucleoplasty) was performed on an outpatient basis under monitored anesthesia care in the operating room of an ambulatory surgical center. All procedures were performed using a strict sterile technique by the corresponding author. Under fluoroscopic guidance with the patient in a prone or semi-oblique position, a 17-gauge sixinch long Crawford type spinal access cannula was placed at the junction of the annulus and nucleus. A Perc-DLE wand (ArthroCare, Inc. - Sunnyvale, CA) was advanced into the disc via the spinal access cannula. After confirming proximal and distal channel limits within the disc, disc decompression was initiated. The decompression process involved advancing the wand, in ablation mode, to the distal channel limit at a speed of $0.5 \mathrm{~cm} / \mathrm{sec}$ and, retraction of the wand in coagulation mode, to the proximal channel limit at the same speed. Six channels were created at the twelve, two, four, six, eight, and ten o'clock positions.

Post-operatively, patients were allowed to perform limited walking, standing, and sitting as needed during activities of daily living, however, they were instructed to limit bending and stooping and lifting less than 10 pounds for 2 weeks. Patients with sedentary or light work environments were allowed to return to work after two weeks. Home exercise instructions were provided to patients by a qualified instructor.

\section{Outcome Measures}

Patients were asked to complete a questionnaire via phone or during post- 
procedure physician visit at $1,3,6$, and 12 months. Outcome measures included self-reported pain score on a numeric pain scale (with 0 being no pain and 10 being the most severe pain) and percent of pain relief as compared to the intensity of pain prior to the procedure. Functional improvement was measured based on patients reported ability to sit, stand, and walk without significant or intolerable pain in the following categories: less than $15 \mathrm{~min} ., 15$ to 30 min., 30 to $45 \mathrm{~min}$., $45 \mathrm{~min}$. to 1 hour, 1 to 2 hours, and greater than 2 hours.

\section{Statistical Analysis}

Outcome measure data was compared between pre-treatment and each post-treatment period. Means, ranges, and standard deviations (SD) were calculated using a Microsoft ${ }^{\circledR}$ Excel work sheet. For percentage outcomes and non-parametric values, 95\% confidence intervals and Wilcoxon signed rank test were used to determine statistical significance, respectively. Variations in outcome data between subgroups based on demographic characteristics (age, weight, etc.) were determined using the Student's $t$-test with a two-tailed comparison. Results were considered statistically significant if the $p$ value was equal to or less than 0.05 for continuous variables.
Table 1. Demographic characteristics

\begin{tabular}{|l|l|l|}
\hline \multirow{3}{*}{ Gender } & Male & $30 \%(24)$ \\
\cline { 2 - 3 } Age (Years) & Female & $70 \%(56)$ \\
\hline \multirow{3}{*}{ Onset of Pain } & Mean \pm SD & $44.8 \pm 10.1$ \\
\cline { 2 - 3 } & Range & $15-62$ \\
\hline \multirow{2}{*}{$\begin{array}{l}\text { Duration of Pain } \\
\text { (Years) }\end{array}$} & Traumatic & $15 \%(12)$ \\
\cline { 2 - 3 } & Non-traumatic & $85 \%(68)$ \\
\hline BMI (Body Mass Index) & Mean \pm SD & $5.5 \pm 6.0$ \\
\hline \multirow{3}{*}{ Smoking Habits } & Range & $0.25-30$ \\
\hline \multirow{3}{*}{ Level(s) of Decompression } & Mean \pm SD & $29 \pm 5.6$ \\
\hline & Nonsmoking & $65 \%(63)$ \\
\cline { 2 - 3 } & Smoking & $35 \%(28)$ \\
\hline \multirow{3}{*}{ Distribution of Primary Pain } & Single level & $79 \%(54)$ \\
\cline { 2 - 3 } & Multi-level & $21 \%(13)$ \\
\hline & Mostly Back & $71 \%(57)$ \\
\cline { 2 - 3 } & Mostly Leg & $9 \%(7)$ \\
\cline { 2 - 3 } & Equal Back and Leg & $9 \%(7)$ \\
\cline { 2 - 3 } & Other & $11 \%(6)$ \\
\hline
\end{tabular}

\section{REsults}

\section{Patient Characteristics}

A total of 80 patients, 56 females and 24 males, aged $15-62$ (44.8 \pm 10.1 years $)$ underwent Percutaneous Disc Decom- pression. Data was collected for sixtynine of 80 patients $(86 \%)$ at 12 months. Of the eleven patients not included, five patients had suffered re-injury or a new injury due to a fall within 4 months of the procedure and 6 patients were lost to follow-up due to relocation. Participant

\section{Table 2. Influence of demographic characters on post-Nucleoplasty numeric pain score at 12 months}

\begin{tabular}{|c|c|c|c|}
\hline Variable & \multicolumn{2}{|c|}{12 Month Numeric Pain Score Values } & $\mathrm{p}$ - value \\
\hline \multirow{2}{*}{ Gender } & Male $(\mathrm{N}=18)$ & Female $(\mathrm{N}=51)$ & \multirow{2}{*}{0.49} \\
\hline & 4.08 & 4.60 & \\
\hline \multirow{2}{*}{ Age (Years) } & $15-44$ yrs (31) & $>44$ yrs (38) & \multirow{2}{*}{0.18} \\
\hline & 3.98 & 4.86 & \\
\hline \multirow{2}{*}{ Onset of Pain } & Traumatic (58) & Non-traumatic (11) & \multirow{2}{*}{0.95} \\
\hline & 4.44 & 4.59 & \\
\hline \multirow{2}{*}{ Duration of Pain } & Pain < 3 yrs (20) & Pain $\geq 3$ yrs (49) & \multirow{2}{*}{0.48} \\
\hline & 4.83 & $4 \cdot 32$ & \\
\hline \multirow{2}{*}{ Body Mass Index } & < $30(43)$ & $\geq 30(26)$ & \multirow{2}{*}{0.34} \\
\hline & 4.22 & 4.87 & \\
\hline \multirow{2}{*}{ Smoking Habits } & Nonsmoking (44) & Smoking (25) & \multirow{2}{*}{0.60} \\
\hline & 4.24 & 4.86 & \\
\hline \multirow{2}{*}{ Level(s) of Decompression } & Single level (54) & Multi-level (15) & \multirow{2}{*}{0.20} \\
\hline & 4.69 & 3.67 & \\
\hline \multirow{2}{*}{ Distribution of Primary Pain } & Primary Back (46) & Other (23) & \multirow{2}{*}{0.42} \\
\hline & 4.65 & 4.09 & \\
\hline \multirow{2}{*}{ Previous Surgical Intervention } & Yes (6o) & No (9) & \multirow{2}{*}{0.14} \\
\hline & 4.28 & 5.72 & \\
\hline
\end{tabular}




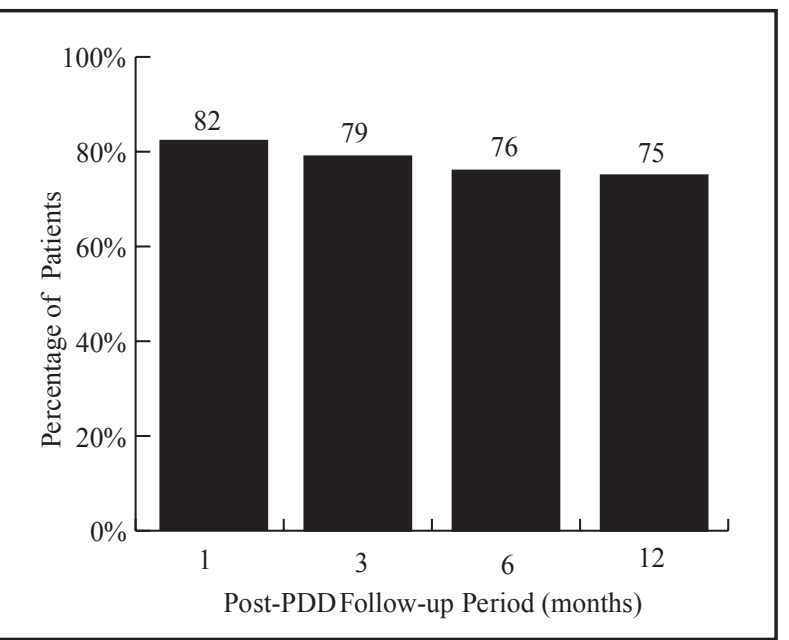

Fig 1. Proportion of patients reporting improvement in numeric pain scores post-percutaneous disc decompression (PDD)

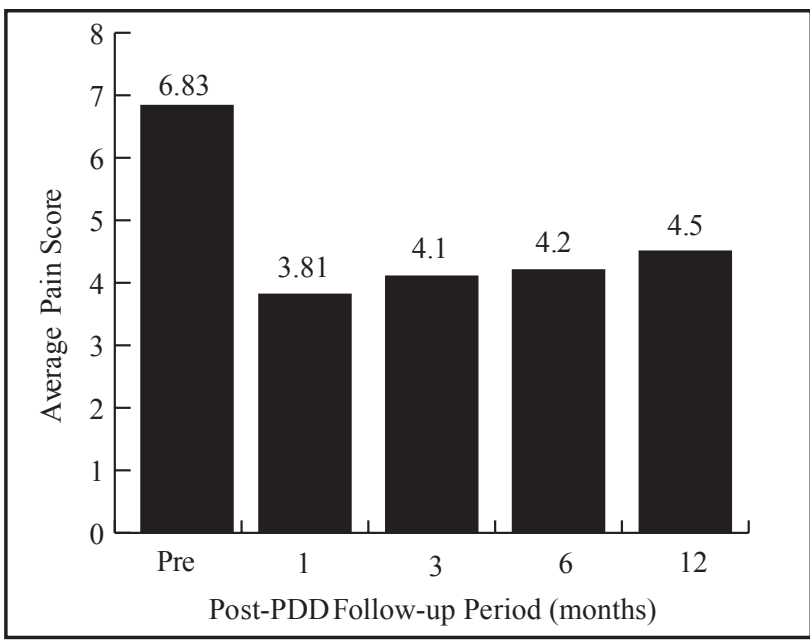

Fig 2. Self-reported numeric pain score pre and postNucleoplasty characteristics are shown in Table 1. Influence of demographic characters on post-Nucleoplasty numeric pain score at 12 months showed no statistically significant differences (Table 2).

\section{Outcomes}

Overall, 75\% (52/69) of patients indicated a decrease in their numeric pain scores at 12 months (Fig. 1 and Table 3) with a statistically significant reduction in numeric pain scores of $2.43 \pm 2.47$ $(p<0.0001)$ compared to baseline (Fig. $2)$. A total of $54 \%$ of patients indicat- ed pain relief of $50 \%$ or more at twelve months (Fig. 3). Additionally, 54\%, 44\%, and $49 \%$ of patients indicated statistically significant improvement in sitting, standing and walking ability, respectively, at 12 months as compared to baseline (Tables 4-6).

\section{Employment}

Ten patients $(15 \%)$ who had previously been unemployed secondary to back pain improved enough to rejoin the work force.

\section{Safety}

There were no complications associated with the PDD procedure using $\mathrm{Co}-$ blation technology during the procedure or post-operatively. Specifically, there were no instances of discitis, dural tear, or neurological deficit related to the procedure.

\section{DISCUSSION}

Chronic back pain is a ubiquitous and functionally disabling condition. Back pain is frequently of multifactorial etiology with several different pain gen-

Table 3. Numeric pain score results reported by patients post-percutaneous disc decompression (PDD)

\begin{tabular}{|c|c|c|c|c|}
\hline & \multicolumn{2}{|c|}{$\begin{array}{c}\text { Patients reporting improvement in } \\
\text { numeric pain scores (\%) }\end{array}$} & \multicolumn{2}{c|}{ Average Improvement in Pain Scores from Baseline } \\
\hline Follow-up & Percentage & $\begin{array}{c}95 \% \text { Confidence Interval } \\
\text { (Low, High) }\end{array}$ & Average \pm SD & p values \\
\hline 1 month $(\mathrm{N}=79)$ & $82 \%$ & $(72 \%, 90 \%)$ & $3.04 \pm 2.29$ & $<0.0001$ \\
\hline 3 month $(\mathrm{N}=75)$ & $79 \%$ & $(68 \%, 87 \%)$ & $2.79 \pm 2.50$ & $<0.0001$ \\
\hline 6 month $(\mathrm{N}=72)$ & $76 \%$ & $(65 \%, 86 \%)$ & $2.67 \pm 2.62$ & $<0.0001$ \\
\hline 12 month $(\mathrm{N}=69)$ & $77 \%$ & $(65 \%, 86 \%)$ & $2.43 \pm 2.47$ & $<0.0001$ \\
\hline
\end{tabular}

Table 4. Proportion of patients reporting sitting ability prior to and after PDD

\begin{tabular}{|c|c|c|c|c|}
\hline \multirow{2}{*}{ Time } & \multicolumn{4}{|c|}{ (Number of Patients) } \\
\hline & Pre-PDD $(\mathrm{N}=80)$ & 3 month $(\mathrm{N}=75)$ & 6 month $(\mathrm{N}=72)$ & 12 month $(\mathrm{N}=69)$ \\
\hline$\ll 15 \min$ & $54 \%(43)$ & $24 \%(18)$ & $35 \%(25)$ & $38 \%(26)$ \\
\hline $15-30 \mathrm{~min}$ & $20 \%(16)$ & $8 \%(6)$ & $8 \%(6)$ & $12 \%(8)$ \\
\hline $30-45 \mathrm{~min}$ & $9 \%(7)$ & $20 \%(15)$ & $7 \%(5)$ & $6 \%(4)$ \\
\hline $45 \mathrm{~min}-1 \mathrm{hr}$ & $5 \%(4)$ & $4 \%(3)$ & $7 \%(5)$ & $6 \%(4)$ \\
\hline $1-2 \mathrm{hr}$ & $3 \%(2)$ & $16 \%(12)$ & $4 \%(3)$ & $4 \%(3)$ \\
\hline $12 \mathrm{hr}$ & $10 \%(8)$ & $28 \%(21)$ & $39 \%(28)$ & $35 \%(24)$ \\
\hline Significance of Improvement from Pre-Op & $\mathrm{N} / \mathrm{A}$ & $<0.0001$ & $<0.0001$ & 0.0001 \\
\hline
\end{tabular}




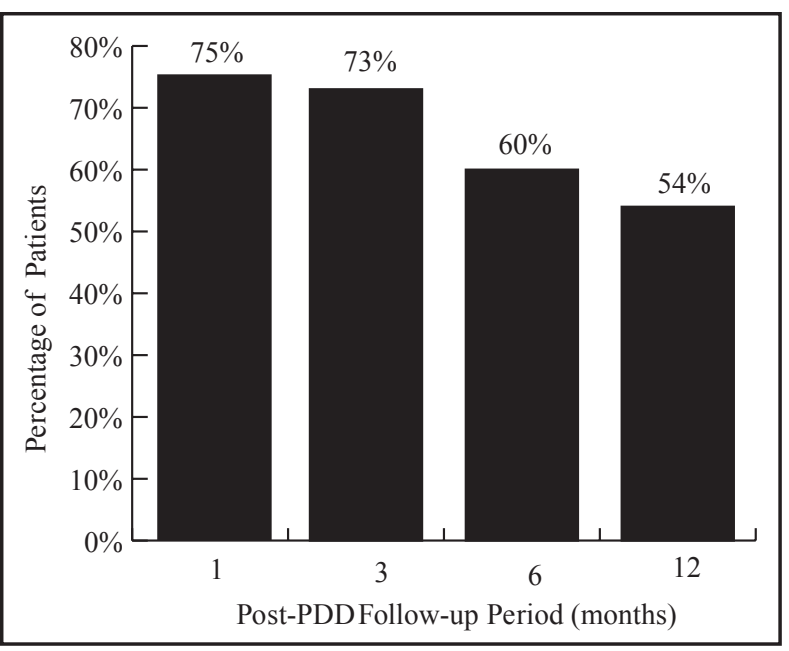

Fig 3. Proportion of patients reporting $50 \%$ more pain relief post-percutaneous disc decompression (PDD)

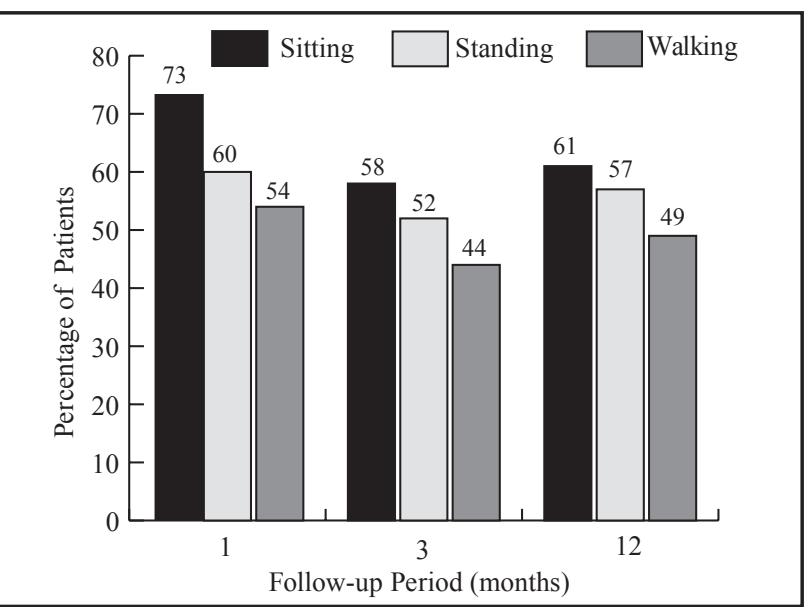

Fig 4. Proportion of patients reporting an increase in duration of sitting, standing and walking ability postpercutaneous disc decompression (PDD) erators in the back and the spine con- normal on imaging studies (42-45). Distributing to a patient's symptoms (39, cography has also been shown to improve 40). Discogenic pain is one of the major components of the low back pain syndrome. Imaging modalities including CT and MRI are frequently used to screen for disc disease. There is however, less than optimum correlation between visualized structural abnormalities and a pain-generating disc (41). Discography remains the mainstay for isolating the pain-generating disc from one which appears ab- cography has also been shown to improve
outcome following surgical interventions involving both open procedures as well as minimally invasive techniques (46-48). Patients included in our analysis had undergone discography to localize the pain generating disc level.

Management of discogenic pain is difficult and complex, and riddled with high failure rates (48). Traditional treatment methods have included physical therapy, activity modification, NSAIDS and fluoroscopically guided injection therapies, all with varying degrees of success. There is a wide body of literature on the potential adverse effects of long term NSAID and acetaminophen use. Several of these studies from this country (49, 50), as well as Europe (51-53) have made an epidemiological correlation between the use of these medications and the development of renal failure. In a case-control study, Kaye et al (54) reported a slight

Table 5. Proportion of patients reporting standing ability prior to and after PDD

\begin{tabular}{|l|c|c|c|c|}
\hline \multirow{2}{*}{\multicolumn{2}{|c|}{ Time }} & \multicolumn{4}{c|}{ (Number of Patients) } \\
\cline { 2 - 5 } & Pre-PDD (N=80) & $\mathbf{3}$ month (N=75) & $\mathbf{6}$ month (N=72) & 12 month (N=69) \\
\hline $115 \mathrm{~min}$ & $61 \%(49)$ & $33 \%(25)$ & $38 \%(27)$ & $42 \%(29)$ \\
\hline $15-30 \mathrm{~min}$ & $21 \%(17)$ & $12 \%(9)$ & $14 \%(10)$ & $9 \%(6)$ \\
\hline $30-45 \mathrm{~min}$ & $3 \%(2)$ & $17 \%(13)$ & $7 \%(5)$ & $12 \%(8)$ \\
\hline $45 \mathrm{~min} \mathrm{-1} \mathrm{hr}$ & $3 \%(2)$ & $3 \%(2)$ & $3 \%(2)$ & $4 \%(3)$ \\
\hline $1-2 \mathrm{hr}$ & $3 \%(2)$ & $8 \%(6)$ & $13 \%(9)$ & $4 \%(3)$ \\
\hline $12 \mathrm{hr}$ & $10 \%(8)$ & $27 \%(20)$ & $26 \%(19)$ & $29 \%(20)$ \\
\hline Significance of Improvement from Pre-Op & N/A & $<0.0001$ & 10.0001 & 0.0005 \\
\hline
\end{tabular}

Table 6. Proportion of patients reporting walking ability prior to and after PDD

\begin{tabular}{|l|c|c|c|c|}
\hline \multirow{2}{*}{ Time } & \multicolumn{4}{|c|}{ (Number of Patients) } \\
\cline { 2 - 5 } & Pre-PDD (N=80) & 3 month (N=75) & $\mathbf{6}$ month (N=72) & 12 month (N=69) \\
\hline $15 \mathrm{~min}$ & $55 \%(44)$ & $29 \%(22)$ & $33 \%(24)$ & $42 \%(29)$ \\
\hline $15-30 \mathrm{~min}$ & $20 \%(16)$ & $12 \%(9)$ & $11 \%(8)$ & $7 \%(5)$ \\
\hline $30-45 \mathrm{~min}$ & $5 \%(4)$ & $15 \%(11)$ & $7 \%(5)$ & $7 \%(5)$ \\
\hline $45 \mathrm{~min}-1 \mathrm{hr}$ & $5 \%(4)$ & $4 \%(3)$ & $4 \%(3)$ & $3 \%(2)$ \\
\hline $1-2 \mathrm{hr}$ & $3 \%(2)$ & $9 \%(7)$ & $11 \%(8)$ & $7 \%(5)$ \\
\hline $12 \mathrm{hr}$ & $13 \%(10)$ & $31 \%(23)$ & $33 \%(24)$ & $33 \%(23)$ \\
\hline Significance of Improvement from Pre-Op & N/A & $<0.0001$ & $<0.0001$ & 0.0008 \\
\hline
\end{tabular}


increase in renal cancer with heavy acetaminophen use. In a comment in the Hypertension journal, Dedier et al (55) reported a significantly increased trend towards incidental hypertension with increased use of aspirin, acetaminophen and other NSAIDs.

Long-term opiate therapy for benign pain is controversial. Although it may be effective in controlling the pain symptoms nonetheless there are concerns regarding abuse, dependence and diversion for illicit use (56-61).

Concerns over the long term usage of NSAIDs, acetaminophen and opiates have prompted a need for a treatment method/methods, which would reduce the long term usage of these medications for control of benign discogenic spinal pain. Minimally invasive intradiscal techniques have emerged as viable options for this indication. In a recent analysis from the U.K., Knight and Goswami (62) have reported sustained clinical benefit in 52\% and functional improvement in an additional $21 \%$ of 348 patients treated with a KTP 532 laser. Others including Bosacco et al (63) and Pettine and Donner (64) have reported success rates ranging from 54 to $60 \%$. Similar results have been reported for IDET by Saal and Saal (65), Singh (66) and Wetzel and McNally (67).

Percutaneous disc decompression using Coblation technique (Nucleoplasty) is yet another therapeutic option. Coblation has been in use for orthopedic arthroscopic procedures since the mid 1990s (68-70) and was approved for use in the spine in 2000. Nucleoplasty using Coblation technology involves the use of Radio-frequency energy to dissolve the nuclear material through molecular dissociation (68). The technique, offers a minimally invasive option of disc decompression while causing very little disruption of the surrounding tissue (71). Preserving the integrity of these tissues may maintain the flow of nutrients to the cells of the nucleus pulposus, resulting in an increased degree of cellular rejuvenation following the procedure. As several studies by $\mathrm{Mo}-$ chida et al $(24,72)$ and Sortland et al (25) have indicated, there appears to be an inverse correlation between the amount of disc material removed and the long term results. Excessive tissue removal leads to accelerated disc degeneration and instability. The Coblation procedure is also attractive in this regard as it involves removal of only a small amount of disc material, typically in the range of $1 \mathrm{ml}$ (68).

This prospective, non-randomized study shows significant improvement in the pain relief and functional improvement for a patient group who were unable to find relief through conservative therapies.

As borne out by the results of this analysis, Percutaneous disc decompression using Coblation techniques, represents an effective method to add to our existing armamentarium for the treatment of discogenic low back pain. It may be argued that this was not a blinded, randomized controlled analysis, however it has been noted in several studies (73-75), that the results of non-randomized or observational studies are not necessarily inferior to those from randomized, double blinded, controlled trials. The typical double-blinded pharmacological trials involve a drug versus placebo. Designing a similar blinded trial for an invasive procedure versus a control or placebo arm presents logistic difficulties, since not doing the procedure in the control arm in itself would un-blind the study. While a sham procedure arm could be incorporated as a control arm, it would pose further ethical and medico-legal dilemmas. The large sample size in our analysis is very significant from a statistical standpoint.

Future research could also be directed towards increasing oxygenation during the procedure to enhance cellular metabolism and promote healing (76), implantation of healthy disc cells to replenish disc height and stability (77), or application of growth factors to repair the annular tissue $(78,79)$.

\section{Conclusion}

In conclusion, the preliminary results of a prospective, non-randomized series showed that disc decompression using Coblation (Nucleoplasty) is a safe and effective procedure in alleviating discogenic back pain, with or without leg pain. The results of this study demonstrated a statistically significant improvement in pain and functional status at 12 months.

\section{Author Affiliation:}

Vijay Singh, MD

Medical Director

Pain Diagnostics Associates

1601 Roosevelt Road

Niagara, Wisconsin 54151

E-mail vsingh@netnet.net

\section{Chandur Piryani, MD}

Interventional Pain Physician

Pain Diagnostics Associates

1601 Roosevelt Road

Niagara, Wisconsin 54151

\section{Katherine Liao, MD}

Interventional Pain Physician

Pain Diagnostics Associates

1601 Roosevelt Road

Niagara, Wisconsin 54151

\section{RefERENCES}

1. Adams M. Laboratory model of lumbar disc protrusion: fissure and fragment. Spine 1994; 19:2015-2017.

2. Butler D, Trafimow JH, Andersoon GB et al. Discs degenerate before facets. Spine 1990; 15:111-113.

3. Maroudas A, Stockwell RA, Nachemson $A$ et al. Factors involved in the nutrition of the human lumbar intervertebral disc: Cellularity and diffusion of glucose in vitro. J Anat 1975; 120:113-130.

4. Bartels EM, Fairbank JCT, Winlove CP et al. Oxygen and lactate concentrations measured in vivo in the intervertebral discs of patients with scoliosis and back pain. Spine 1998; 23:1-8.

5. Buckwalter JA. Aging and degeneration of the human intervertebral disc. Spine 1995; 20:1307-1314.

6. Mirza SK, White AA. Anatomy of intervertebral disc and pathophysiology of herniated disc disease. I Clin Laser Med Surg 1995; 13:131-142.

7. Eyre DR. Biochemistry of the intervertebral disc. Rev Conn Tissue Res 1979; 8: 227-291.

8. Guiot B, Fessler R. Molecular biology of degenerative disc disease. Neurosurgery 2000; 47:1034-1040.

9. Holm S, Maroudas A, Urban JPG. Nutrition of the intervertebral disc: Solute transport and metabolism. Conn Tissue Res 1981; 8: 101-119.

10. Markolf KL, Morris JM. Deformation of the thoracolumbar intervertebral joints in response to external loads. J Bone Joint Surg 1972; 54A:511-533.

11. Bogduk N. The inter-body joints and the intervertebral discs. In Clinical Anatomy of the Lumbar Spine and Sacrum, ed 3. Churchill Livingstone, New York, 1997, pp 13-32. 
12. White AA, Panjabi MM. Clinical Biomechanics of the Spine, $2^{\text {nd }}$ ed. JB Lippincott, Philadelphia, 1990.

13. Yamashita T, Minaki Y, Oota I et al. Mechanosensitive afferent units in the lumbar intervertebral disc and adjacent muscle. Spine 1993; 18:2252-2256.

14. McCarthy PW, Carruthers B, Martin D et al. Immunohistochemical demonstration of sensory nerve fibers and endings in lumbar intervertebral discs of the rat. Spine 1991; 16:653-655.

15. Bogduk $N$ (ed). Nerves of the lumbar spine. In Clinical Anatomy of the Lumbar Spine and Sacrum, ed 3. Churchill Livingstone, New York, 1997, pp 127-144. 16.

16. Bogduk N, Tynan W, Wilson AS. The innervation of the human lumbar intervertebral discs. J Anat 1981; 132:39-56.

17. Freemont AJ, Peacock TE, Goupille $P$ et al. Nerve ingrowth into diseased intervertebral disc in chronic back pain. Lancet 1997; 350:178

18. Ashton IK, Roberts S, Jaffray DC et al. Neuropeptides in the human intervertebral disc. J Orthop Res 1994; 12:186-192.

19. Boden SD, Davis DO, Dina TS et al. Abnormal magnetic-resonance scans of the lumbar spine in asymptomatic subjects. A prospective investigation. J Bone Joint Surg Am 1990; 72:403-408.20.

20. Coppes MH, Marani E, Thomeer RT et al. Innervation of "painful" lumbar discs. Spine 1997; 22:2342-2350.

21. Mixter WJ, Barr JS. Rupture of the intervertebral disc with involvement of the spinal canal. N Eng J Med 1934; 211:210-215.

22. Carragee EJ, Suen P, Han M et al. Can MR Scanning in Patients with Sciatica Predict Failure of Open Limited Discectomy? In Proceedings of the International Society for the Study of Lumbar Spine (ISSLS). Scotland, June 2001.

23. Carragee EJ, Han MY, Suen PW et al. Clinical outcomes after lumbar discectomy for sciatica: the effects of fragment type and anular competence. J Bone Joint Surg Am 2003; 85-A:102-108.

24. Mochida J, Nishimura K, Nomura $T$ et al. The importance of preserving disc structure in surgical approaches to lumbar disc herniation. Spine 1996; 21:1556-1564.

25. Sortland O, Kleppe H, Aandahl M et al. Percutaneous lumbar discectomy: Technique and clinical result. Acta Radiologica 1996; 37:85-90.

26. Mochida J, Tos E, Nomura T et al. The risks and benefits of percutaneous nucleotomy for lumbar disc herniation: A 10-year longitudinal study. J Bone Joint Surg Br 2001; 83:501-505.

27. Ahlgren BD, Lui W, Herkowitz $\mathrm{HN}$ et al. Effect of anular repair on the healing strength of the intervertebral disc: A sheep model. Spine 2000; 25:165-170.

28. Stathopoulos PC, Cramer GD. Microscopic anatomy of the zygapophyseal joints and intervertebral discs. In Cramer GD, Dar- by SA (eds.) Basic and Clinical Anatomy of the Spine, Spinal Cord and ANS. Mosby Year Book, Inc., St. Louis, 1995, pp 393419.

29. Ahlgren BD, Vasavada A, Brower RS et al. Anular incision technique on the strength and multidirectional flexibility of the healing intervertebral disc. Spine 1994; 19: 948-994.

30. Ethier DB, Cain JE, Yaszemski MJ et al. The influence of annulotomy selection on disc competence. A radiographic, biomechanical, and histologic analysis. Spine 1994; 19:2071-2076.

31. Natarajan RN, Andersson GB, Patwardhan AG et al. Effect of annular incision type on the change in biomechanical properties in a herniated lumbar intervertebral disc. Biomech Eng 2002; 124:229-236.

32. Songer MN, Ghosh L, Spencer DL. Effects of sodium hyaluronate on peripheral fibrosis after lumbar laminotomy and discectomy. Spine 1990; 15:550-554.

33. Jayson MIV. The role of vascular damage and fibrosis in the pathogenesis of nerve root damage. Clin Orthop 1992; 279:4048.

34. Sharps L, Isaac Z. Percutaneous disc decompression using Nucleoplasty®. Pain Physician 2002; 5:121-126.

35. Singh V, Piryani C, Liao K et al. Percutaneous disc decompression using coblation (Nucleoplasty) in the treatment of chronic discogenic pain. Pain Physician 2002; 5 : 250-259.

36. Slipman CW, Bhat AL, Gilchrist RV et al. Preliminary results for axial low back pain treated with Coblation: A comparison of patients with and without central focal protrusion. Eur Spine J 2002; 11:416-417.

37. Chen YC, Lee S, Lau E. Percutaneous disc decompression: Nucleoplasty for chronic discogenic pain with or without sciatica. In Proceedings of the North American Spine Society/South American Spine Society, NASS Meeting of the Americas, New York City, April 2002.

38. Jones SC, Fernau RC, Buemi JM. Six months follow-up on lumbar disc Nucleoplasty in 45 patients. In Proceedings of the North American Spine Society/South American Spine Society, NASS Meeting of the Americans, New York City, 2002.

39. Manchikanti L, Singh V, Pampati V et al. Evaluation of the relative contributions of various structures in chronic low back pain. Pain Physician 2001; 4:308-316.

40. Singh V. Pathophysiology of the disc. In Manchikanti L, Slipman CW, Fellows B (eds), Interventional Pain Management: Low Back Pain - Diagnosis and Treatment. ASIPP Publishing, Paducah, KY 2002; pp 59-68.

41. Parfenchuck TA, Janssen ME. A correlation of cervical magnetic resonance imaging and discography/computed tomographic discograms. Spine 1994; 19:2819-2825.

42. Fortin JD, Sehgal N, Nieves RA. Lumbar and thoracic discography with $\mathrm{CT}$ and MRI correlation. In Lennard TA (ed). Pain Procedures in Clinical Practice. Hanley and Belfus, Inc., Philadelphia, 2000, pp 241264.

43. Manchikanti L, Singh V, Pampati V et al. Provocative discography in low back pain patients with or without somatization disorder: A randomized, prospective evaluation. Pain Physician 2001; 4:227-249.

44. Ohnmeiss DD, Guyer RD, Hochshuler SH. Laser disc decompression. The importance of proper patient selection. Spine 1994; 19:2054-2058.

45. Manchikanti L, Staats P, Singh V et al. Evidence-based practice guidelines for interventional techniques in the management of chronic spinal pain. Pain Physician 2003; 6:3-80.

46. Colhoun E, McCall IW, Williams L et al. Provocative discography as a guide to planning operations on the spine. J Bone Joint Surg 1988; 70:267-271.

47. Collins HR. An evaluation of cervical and lumbar discography. Clin Orthop 1975; 107:133-138.

48. Singh V, Slipman C. Discogenic pain and intradiscal therapies. In Manchikanti L, Slipman CW, Fellows B (eds), Interventional Pain Management: Low Back Pain - Diagnosis and Treatment. ASIPP Publishing, Paducah, KY 2002; 411-420.

49. Perneger TV, Whelton PK, Klag MJ. Risk of kidney failure associated with the use of acetaminophen, aspirin and nonsteroidal antiinflammatory drugs. N Engl J Med 1994; 331:1675-1679.

50. Buckalaew VM Jr. Habitual use of acetaminophen as a risk factor for chronic renal failure: A comparison with phenacetin. Am J Kidney Dis 1996; 28:S7-S13.

51. Fored CM, Ejerblad E, Lindblad P et al. Acetaminophen, aspirin, and chronic renal failure. N Engl J Med 2001; 345:1801-1808.

52. Pommer W, Bronder E, Greisser E et al. Regular analgesic intake and the risk of end-stage renal failure. Am J Nephrol 1989; 9:403-412.

53. Evans JM, McGregor E, McMahon AD et al. Non-steroidal anti-inflammatory drugs and hospitalization for acute renal failure. QJM 1995; 88:551-557.

54. Kaye JA, Myers MW, Jick H. Acetaminophen and the risk of renal and bladder cancer in the general practice research database. Epidemiology 2001; 12:690-694.

55. Dedier J, Stampfer MJ, Hankinson SE et al. Non-narcotic analgesic use and the risk of hypertension in US women. Hypertension 2002; 40:601-603.

56. Simoni-Wastila L, Tompkins C. Balancing diversion control and medical necessity: The case of prescription drugs with abuse potential. Subst Use Misuse 2001; 36:1275-1296

57. Manchikanti L, Brown K, Singh V. National All Schedules Prescription Electronic Reporting Act (NASPER): Balancing substance abuse and medical necessity. Pain Physician 2002; 5:294-319. 
58. Atluri S, Boswell M, Hansen $\mathrm{H}$ et al. Guidelines for the use of controlled substances in the management of chronic pain. Pain Physician 2003; 6:233-257.

59. Manchikanti L, Damron K, Beyer C et al. A comparative evaluation of illicit drug use in patients with or without controlled substance abuse in interventional pain management. Pain Physicians 2003; 6: 281285.

6o. Manchikanti L, Pampati V, Damron K et al. Prevalence of illicit drug use in patients with or without controlled substance abuse in interventional pain management. Pain Physician 2003; 6: in press.

61. Manchikanti L, Pampati V, Damron K et al. Prevalence of illicit drug use in patients without controlled substance abuse in interventional pain management. Pain Physician 2003; 6:173-178.

62. Knight M, Goswami A. Lumbar percutaneous KTP 532 wavelength laser disc decompression and disc ablation in management of discogenic pain. J Clin Laser Med Surg 2002; 20:9-13.

63. Bosacco SJ, Bosacco DN, Berman AT et al. Functional results of percutaneous laser discectomy. Am J Orthop 1996; 25:825-828.

64. Pettine KA, Donner EJ. Can percutaneous laser discectomy prevent lumbar fusion? In Proceedings of International Intradiscal Therapy Society, Tenth Annual Meeting, Naples, FL, May 1997.

65. Saal JA, Saal JS. Intradiscal electrothermal treatment for chronic discogenic low back pain: A prospective outcome study with minimum 1-year follow-up. Spine 2000; 25:2622-2627.

66. Singh V. Intradiscal electrothermal therapy: A preliminary report. Pain Physician 2000; 3:367-373.

67. Wetzel FT, McNally TA. Treatment of chronic discogenic low back pain with intradiskal electrothermal therapy. J Am Acad Orthop Surg 2003; 11:6-11.

68. Eggers PE, Thapliyal HV, Matthews LS. Coblation: A newly described method for soft tissue surgery. Research Outcomes in Arthroscopic Surgery 1997: 2:1-4

69. Yetkinler D, Bessette A, Wolozko J. A novel radiofrequency technology (Coblation) for dermatologic surgery applications. In Proceedings of BIOS/SPIE Annual Meeting. San Jose, CA, January 2002.

70. Yetkinler D, Lee K, Brandt L, et al. A novel radiofrequency technology (coblation) for ear, nose and throat surgery applications. In Proceedings of BIOS/SPIE Annual Meeting. San Jose, CA, January 2002.

71. Chen YC, Lee S, Date ES, et al. Histology findings of disc and neural tissues status post percutaneous disc decompression: Nucleoplasty (coblation technology): An experimental study. In Proccedings of ISIS 9th Annual Scientific Meeting. San Francisco, CA, September 2001.

72. Mochida J, Nishimura K, Okuma $M$ et al. Percutaneous nucleotomy in elite athletes. J Spinal Disord 2001; 14:159-164.

73. Concato J, Shah N, Horwitz RI. Random- ized controlled trials, observational studies, and the hierarchy of research designs. N Engl J Med 2000; 342: 1887-1892.

74. Benson K, Hartz AJ. A comparison of observational studies and randomized, controlled trials. N Engl J Med 2000; 342 1887-1892.

75. Manchikanti L, Heavner J, Racz G et al. Methods for evidence synthesis in interventional pain management. Pain Physician 2003; 6:89-111.

76. Ishihara H, Urban JP. Effects of low oxygen concentrations and metabolic inhibitors on proteoglycan and protein synthesis rates in the intervertebral disc. J Orthop Res 1999; 17:829-835.

77. Alini M, Roughley PJ, Antoniou J et al. A biological approach to treating disc degeneration: Not for today, but maybe tomorrow. Eur Spine J 2002; 11:15-20.

78. Melrose J, Smith S, Little CB et al. Spatial and temporal localization of transforming growth factor-beta, fibroblast growth factor-2, and osteonectin, and identification of cells expressing alpha-smooth muscle acting in the injured anulus fibrosus: Implications for extracellular matrix repair. Spine 2002; 15:1756-1764.

79. Meirisch CM, Cohen SB, Jordan LC et al. Transforming growth factor-beta in calcium alginate beads for the treatment of articular cartilage defects in the rabbit. $\mathrm{Ar}$ throscopy 2002; 18:892-900. 